\title{
THE INTERACTIVE EFFECTS OF REMITTANCES ON ECONOMIC GROWTH AND INEQUALITY IN WESTERN BALKAN COUNTRIES
}

\author{
Ujkan Q. BAJRA (D) $1,2^{*}$ \\ ${ }^{1}$ Institute for Economic Research and Legal Studies, Prishtinë, Kosovo \\ ${ }^{2}$ University of Prishtina, Prishtinë, Kosovo
}

Received 07 September 2020; accepted 01 March 2021

\begin{abstract}
Hardly any studies have investigated the impact of migrant remittances on economic growth (EG) and inequality in the Western Balkans as a whole (WB6). Using the method of instrumental variables (VI), the findings show that while remittances influence economic growth, their inflow also promotes a high level of migration and absorbs a large workforce by influencing the labor market and encouraging uncontrolled individual relocation. This paper also reveals that although remittances have eased income inequalities the share of remittances in a country's economy has declined over the years. After testing for the endogeneity of remittances and controlling for various variables, the results indicate that migrant workers' remittances do not provide strong support for economic growth and inequality. For the sample average, a 1-percent rise in the share of remittances in the economy (i.e., to GDP) will lead to a 0.10 -percent rise in the economic cycle i.e. GDP growth, respectively will lead to a 0.05 -percent drop in the share of people living in inequality. The findings also show that the interactive effect of remittances and foreign direct investment is lower on economic growth and inequality than the individual effect of each factor.
\end{abstract}

Keywords: economic growth, international migration, remittances, inequalities, poverty reduction, foreign direct investments.

JEL Clasification: O1, O4, F22, F24.

\section{Introduction}

The remittances migrant workers send to their countries of origin are included among the factors with an established link with economic growth and income inequality at home. Distinct from their hidden effects, some empirical records suggest remittances have positive links with economic growth and inequality, while others suggest the opposite. A few works show that remittances have neutral effects on either category mentioned. With migration steadily growing around the world, Western Balkan countries (the WB6) have seen a consid-

*Corresponding author. E-mails: ujkan.bajra@ierls.net,ujkan.bajra@uni-pr.edu

Copyright (c) 2021 The Author(s). Published by Vilnius Gediminas Technical University

This is an Open Access article distributed under the terms of the Creative Commons Attribution License (http://creativecommons. org/licenses/by/4.0/), which permits unrestricted use, distribution, and reproduction in any medium, provided the original author and source are credited. 
erable exodus of people in this regard, while the departure of people from the region to other, more prosperous countries is an ongoing process driven by many factors. According to the Global Knowledge Partnership on Migration and Development (KNOMAD, 2020), USD 707 billion in remittances was recorded worldwide in 2019, with the WB6 region attracting some USD 10 billion or an estimated $1.41 \%$ of total global remittances. Overall, Kosovo leads with its share of remittances accounting for $15.1 \%$ of its GDP, followed by Bosnia and Herzegovina with $10.5 \%$, Montenegro with $10.4 \%$, etc.

Remittances are just one of several types of external funding an economy relies on and theoretically represents household income from foreign more prosperous economies, including cash and noncash items that flow through both formal (i.e. via electronic wire) and informal channels (i.e. money carried across borders) (International Monetory Fund, 2009, pp. 250-280). Despite their profound impact on economic activity, the literature shows remittances have different effects on economic growth and inequality. Chowdhury (2016), Etonam Adetou and Fiodendji (2019), and Adams and Cuecuecha (2013) state that not only do remittances affect economic growth but they also influence the financial system, institutional quality, reduce poverty and increase human and physical capital investment in developing countries. In contrast, Amuedo-Dorantes et al. (2010) and Bertoli and Marchetta (2014) list certain negative effects of remittances associated with school attendance for all children regardless of income level, impact on the workforce, uncontrolled migration, etc. Overall, this rich evidence indicates that the effects on the economy and society are multidimensional and that, while it is hard to accurately determine what holds the greatest weight for the existence of remittances, socio-economic factors generally prevail (Dobson \& Sennikova, 2007). The socio-economic factors considered in this study include the age at which one migrates. In fact, second- and third-generation heirs are less involved in sending remittances as their connections with their parents/their countries of origin decline (Alesina \& Giuliano, 2010; World Bank, 2019). Another issue raised by the age at which one migrates is that the Diaspora is shrinking coupled with the low population growth seen in WB6, while at the same time connections with relatives are also fading. The clear outcome of all this is that the WB6 is attracting an ever smaller share of remittances, and that their effect on economic growth might be unmeasurable if their share drops below 7\% of GDP.

In addition, in a socio-economic sense inequality compares an individual's or family's income with an accepted inequality threshold. If people's incomes fall below this threshold (e.g. USD 1.90 per day), they are considered to be extremely poor. The literature broadly shows that inequality manifests in several dimensions like land deprivation, unemployment, family size, healthcare, malnutrition, illiteracy, child labor, etc., (Wietzke, 2020). When these dimensions cannot be met, people become forced to migrate in search of both a better life and the possibility to send some of their earnings home, thereby reducing inequality and the poverty rate in their country of origin (Erman \& te Kaat, 2019; Kuznets, 2019). In so doing, this paper seeks to further develop two issues. The first is the effect of remittances on economic growth while the second is the impact of the inflow of remittances on reducing income inequality in the six Western Balkan countries.

As mentioned, this study makes several contributions. First and perhaps most importantly, while the destination of remittances may vary, this paper also considers the overall 
effect of their use on economic growth and lowering inequality. By covering these specific issues, the study makes an important contribution, especially since countries from the WB6 region are inadequately addressed in previous inquiries. Second, by relying on a cross-country analysis involving steady population growth and high migration flows, this study also contributes substantially to determining whether migrants' ties with their countries of origin are weakening and, thus, whether they have a sufficient influence on economic growth and inequality at home. Third, regardless of the amount of remittances sent, the study shows they do not have a large impact on economic growth since most personal remittances are used for household consumption. In this sense, the study considers whether workers' remittances substitute rather than complement other external funds. Since population growth is another very important factor in economic growth, it is vital to assess whether high levels of migration have lowered the natural population increase and have adverse effects for economic growth and inequalities. To address all these concerns, the paper helps clarify the complex links that international migration and remittances have with the economic and social phenomena mentioned above.

The paper proceeds as follows. Section 1 provides the theoretical framework on the relationship between remittances, growth, and inequality. Section 2 describes the development of the hypotheses. Section 3 outlines the data set and methodology, section 4 discusses the empirical results while last Section concludes.

\section{Theoretical background}

While studies covering the continents of the Americas (i.e., the Diaspora of Latin countries), Africa (i.e., sub-Saharan countries), or Asia predominate (i.e., Pakistan, Bangladesh, India, etc.), not many studies can be found that cover European countries. Even those European countries that have received the attention of scholars are not high-income countries (Haller et al., 2018). On the other side, the WB6 countries as whole have received even less attention, making further research on these issues worthy of attention (de Haas et al., 2019; King \& Vullnetari, 2009; Polat \& Rodríguez Andrés, 2019; Saadi, 2020). Seeing this as an advantage, the paper, in addition to contributing to the body of literature, it provides an insight into the multidisciplinary impact of remittances, whether on economic growth or inequalities reduction.

Unlike for developed countries, remittances are expected to have a greater influence on developing countries, yet the impacts on economic growth and inequality might depend on their final destination (Carletto et al., 2006; Dominese et al., 2020; Duval \& Wolff, 2016). A study provided by Karpestam (2012) shows that the purpose of remittances depends on the income level of the receiving countries, which is consequently oriented towards consumption or investment. According to Pradhan et al. (2008), remittances have a positive impact on the economic growth of developing countries, as expressed in increased purchasing power. Likewise, Rausser et al. (2018) demonstrated that remittances have high and positive impact on economic development, but such an impact is not supported by Mehedintu et al. (2020) who claim that remittances in addition to improving the lives of citizens have also increased the exodus of skilled workers. Guha (2013) also described the significant links 
between macroeconomic effects and remittances such that they directly impact the foreign exchange reserves of developing countries, in turn affecting decisions made on consumption and labor supply and thereby directly lead to reduced poverty or inequality in the country (Acosta et al., 2008; Imai et al., 2014). In short, the literature shows that remittances hold the potential to improve the well-being of the population, stimulate economic growth and thus reduce inequality (Brueckner \& Lederman, 2018; Gapen et al., 2009; Kubis \& Schneider, 2016; Sobiech, 2019), but as Haas (2007) claims, their effects on combating inequality are far more likely than on boosting economic growth.

Some critical voices have questioned whether remittances are delivering their expected impact on economic growth (Bugamelli \& Paternò, 2011). For instance, Clemens and McKenzie (2018) claim that macroeconomic studies have difficulty detecting the effect of remittances on economic growth. Likewise, Gapen et al. (2009) state that workers' remittances have no impact on economic growth. Indications that remittances could have a negative impact on economic growth are related to the reduced labor supply at home that is made available to the receiving country and, in consequence, it could undermine incentives to work (Rodriguez \& Tiongson, 2001), in turn, hindering the level of those actively seeking work. Chami et al. (2018) also show that remittances reduce labor force participation and add to the labor market's informality. Negative effects of remittances are also seen in lower school attendances of children and a rise in child labor (Alcaraz et al., 2012; Sebastian et al., 2019). In addition, remittances affect food price shocks and, given that the shock is a price increase rather than a reduced supply, poor people can be significantly influenced by it. In this sense, Combes et al. (2014) find that the effect of a positive/negative food price shock depends on the size of the remittances, suggesting that a smaller remittance-to-GDP share is required to fully absorb the effects of food price shocks.

Corresponding with the above literature, empirical evidence provides controversial support on the effect the inflow of remittances has on a country's economy, although it is generally accepted that there are more positive than negative effects. These findings are linked with the specifics of the countries, the preservation of ties with the homeland, and the culture and diversity of the people.

\section{Hypotheses development}

Economic growth is influenced by micro and macroeconomic inputs, yet this paper intends to extend the focus to the role of international migrants, namely, the impact the inflow of remittances has on a country's economic cycle and income inequality. By influencing the sense of community for a better life, they further encourage in others the desire to migrate, especially those in the active workforce, with the outcome already being felt in WB6.

As reported by the World Bank in 2019, the economic size of the WB6 is over USD 100 billion. The capacity of the labor force is relatively high, with workers, experts, and skilled professionals being the target of developed countries. Of a total population of 17.1 million, over $31 \%$ or 5.1 million WB6 people held migrant status in 2017, sending approximately USD 10 billion each year back to their countries, but, of course, the added value they create remains in the country in which they work, mainly in Europe. As mentioned, international 
migration has never stopped and movements are driven by a multitude of factors and reasons. On top of socio-economic issues, other factors are involved in driving international migration - political, armed conflicts, better education, family reunification, etc., (Cismaș et al., 2019; Mendoza, 2020). At first glance, remittance inflows are an important factor for economic growth, but one can find exceptions (Chowdhury, 2016; Lartey, 2013). International remittances represent the inflow of cash or noncash items into the economy and accordingly this research aims to empirically confirm whether remittances positively affect growth and whether financial contributions decline as with the connections of migrant workers with their home become weaker (i.e., dependence on remittances). Except for this, the impact of the inflow of remittances has already seen mixed results, with positive or negative correlations (Baškot, 2020; Bertoli \& Marchetta, 2014), but no study thus far has addressed the contradictory aspects mentioned above. Therefore, the following hypothesis is formulated:

Hypothesis 1: Remittances sent by migrant workers contribute significantly to the economic growth of WB6 countries.

The remittances of migrant workers are used for different purposes, including to reduce income inequality. Adams and Cuecuecha (2013) show that both international migration and remittances significantly lower inequality in the developing world, although in the long run they do not seem healthy. Further, they show that households in receipt of remittances spend less at the margin on food and more on education, housing, and health, which greatly reduces the likelihood of household inequality. On this basis, remittances increase people's well-being, mainly via basic consumption, but not such that they can rise in their economic position. After all, no economic evidence shows that inequality has been drastically reduced by remittances if a country does not secure other funding sources, attract foreign investment or return its absorbing power to economic development. The inequality expressed in the GINI coefficient may not show the right economic appearance, although at the aggregate level it shows the distribution of income in the population, which indirectly increases purchasing power parity. Namely, although it is expected that remittances will reduce inequality, the study is not as enthusiastic in believing that remittances have any major effect on the economy. An approximate interpretation of this points to the limited purposes of their use. Therefore, the second main hypothesis is formulated as follows:

Hypothesis 2: Remittances sent by migrant workers have reduced income inequalities in WB6 countries.

\section{Research methodology}

\subsection{Sample description and data}

The paper is based on data on remittances, economic growth, and economic inequality in the six Western Balkan countries known as the WB6. World Bank statistics show the WB6 has a large number of emigrants (around 5 million in 2017) and their main destination is Western Europe or the United States. This paper covers long-term data over a 20 -year period and, unlike most previous research it covers the economic aspect of migration, its benefits but 
also the damage caused to the local labor market and economic activity generally. The main sources of the data are the World Bank, United Nations Statistics, and the statistical agencies and central banks of each WB6 country.

While the paper ensures the validity of the two hypotheses, the data collection and analysis requires the paper to be divided into two periods. Hence, unlike international remittances, in the absence of data on inequality (i.e. second hypothesis) we were forced to shorten the time period to 10 years, i.e., from 2010 to 2019.

The data used in this study cover gross domestic product, gross national income, remittance flows, income inequality (GINI coefficients), foreign direct investment, export/import as a sign of economic openness, and the difference between immigration and emigration (net migration). In this case, some WB6 countries are regularly associated with negative migration flows and this is not a function of economic growth. Moreover, data on the population growth rate were also collected, where natural population growth and age dependency, etc. serve as instrumental variables in this study.

\subsection{Instrumental variables estimation}

The data problems summarized below cast doubt on whether the most common Ordinary Least Squares (OLS) is appropriate because the standard OLS regression method will generally not provide unbiased estimates (i.e., the problem of endogeneity), especially when the sample size is not large, which makes OLS become inconsistent. Simultaneously, this paper uses an instrumental variables (IV) estimation due to consistency and the problem of endogeneity.

Let us first consider the following (reduced form) basic model:

$$
\begin{gathered}
y_{i}=y_{i} \beta_{1}+x_{1 i} \beta_{2}+u_{i} \\
y_{i}=x_{1 i} \Pi_{1}+x_{2 i} \Pi_{2}+v_{i},
\end{gathered}
$$

where $y_{i}$ is the dependent variable, i.e., GDP growth, $y_{i}$ represents the endogenous regressors, i.e., remittances and inequalities, $x_{1 i}$ represents the included exogenous regressors (inflowFDI, OpeEx, netMIG), and $x_{2 i}$ the excluded exogenous regressors (population growth, age dependency, import). From (1), we have $u_{i}=y_{i}-y_{i} \beta_{1}-x_{1 i} \beta_{2}$. By assumption, $x_{1 i}$ is uncorrelated with $u_{i}$ (i.e. it excludes instrument $z$ from being regressors in the model for $y$ ), as are the excluded exogenous variables $x_{2 i}$, and so we use $z_{i}=\left[x_{1 i} x_{2 i}\right]$. Next, the second assumption requires that there be some association between instruments and the variable being instrumented. Therefore, for all of these problems, an instrumental variables estimation can be applied because instrumentals $(z)$ are used to control the correlations between the error term (u) and the exogenous regressors.

In relation to this issue, models in/of Eq. (3) and (4) tend to balance instruments with endogenous regressors, i.e., underidentification and overidentification instruments. Yet, in practice, it is often a good idea to have more instruments than strictly needed because the additional instruments can be used to increase the accuracy of the estimates and build tests for the validity of the identifying barriers (then shedding light on the validity of the instruments). Without going into mathematical details here, the study uses the instrumental variables (IV) estimator method (see Baum et al., 2003; Wooldridge, 2013). 
In addition to the IV estimator, the paper relies on growth theory which states that economic development is determined by several endogenous and exogenous factors on the assumption of a continuous return (Bajra et al., 2020; Hye \& Lau, 2015; Romer \& Romer, 2010). Although it does not exclude other factors, according to the neoclassical approach capital, labor, and technology are the key factors used for optimizing the growth rate (output) (Grossman \& Helpman, 1994). In other words, in this theory the accumulation of capital within an economy depends on how individuals put their commitment to work and use their capital to accelerate economic growth. Further, the technological absorption level is thought to increase labor productivity and boost labor production skills (Mccallum, 1996). On the other side, the endogenous growth model supports the view that the growth rate is determined inside the model rather than outside and, most importantly, this theory suggests that improvements in productivity may be attributed to investment in human capital, the degree of innovation, and technological knowledge (Grossman \& Helpman, 1994). A combination of these input factors therefore promotes economic growth while not reducing the level of inequality in the country. In line with this rationale, two models were used to measure the effects of international remittances and inequality using cross-country data. Thus, the first model helps analyze the effect of remittances on economic growth, while the second model (2) aims to gauge the relationship between international remittances and inequality.

Like with any regression, the problems of endogeneity and heteroskedasticity arise while running the instrumental variables (i.e., 2SLS and GMM) regression estimator. Still, appropriate tests are undertaken and all these problems are localized in line with accepted assumptions. Recent studies on remittances and economic growth use this technique of analysis to compensate for the lack of a good instrumental variable in econometric estimations. Therefore, the econometric model used to estimate the first hypothesis is as follows:

$$
\begin{gathered}
G R_{i t}=\beta_{0}+\beta_{1} \text { inflowREM }_{i t}+\beta_{2} \text { inflowFDI }_{i t}+\beta_{3} \text { OpeEx }_{i t}+ \\
\beta_{4} \text { netMIG }_{i t}+\beta_{5} \text { infREM }{ }^{*} \text { infFDI } \\
i t
\end{gathered}
$$

where GR is the measure of growth $(G R)$ as real GDP per capita in country $i$ at time $t$ and stands as the dependent variable in this study. Next, remittances (inflowREM) represent the test variable of this study, which is the measure of emigrants' remittances to receiving country $i$ at time $t$. Foreign direct investment (inflowFDI) is the measure of an investment as the ratio of foreign direct investment to GDP for country $i$ at time $t$. Openness (OpeEx) is the ratio of export percentage to GDP for country $i$ at time $t$. Net Migration (netMIG) is measured as the difference between immigrants (persons entering the country) and emigrants (persons leaving the country) for country $i$ and time $t$. Further, the model include the infREM *infFDI control variable that acts as an interaction term and measures the mutual effect of remittances and foreign direct investment on economic growth. Next, time-fixed effects $\left(e_{i t}\right)$, country effect $\left(u_{i t}\right)$ and error term $\left(\varepsilon_{i}\right)$ are included in the model.

Thus, Eq. (3) presents the basic model of the study used to measure the impact of emigrants' remittances on economic growth (Sobiech, 2019). As mentioned, economic growth is contingent on several input factors, however, the more wide-ranging the factors, the more stable the growth. Otherwise, national output must be affected by many sources or channels, thereby making having a range of different impacts on economic growth. 
It is very likely that inflowFDI has a multidimensional effect; if capital inflows have a multiplier destination in the economy (i.e., are used to invest in production processes, technology, machinery, equipment, land, etc.). The impact of inflowFDI is not only linear in the sense of economic growth, but affects economic activities by including new knowledge and replacing old technology accordingly (Bajra et al., 2021; Borensztein et al., 1998).

Openness (OpeEx) measures how open an economy is to international trade for each country under consideration. Thus, it measures the ratio of all exports to GDP with the aim to capture the impact of trade and opening the economy on economic growth. As widely supported by the literature, it is expected that OpeEx also has a positive impact on GR (Bermejo Carbonell \& Werner, 2018; Hanushek, 2013). In contrast, there are cases when openness is reported to have a negative effect on the economy. This is especially possible in low-income countries where the inflation rate is high and products are low in quality (Keho, 2017).

Net migration (netMIG) is the difference between population inflows (immigration) and outflows (emigration) and, since labor is the biggest contributor to nation economic output, its impact is inevitable (Peterson, 2017). As a rule, migrant workers make significant contributions to the labor market in both high- and low-skilled professions but, unlike their country of origin, migration in the host country increases both economic growth and the working-age population. Young people are typically those who emigrate and, even if they do not have the skills required in the Western labor market, they are willing to acquire knowledge and contribute to the development of their human capital and the technological progress of the host country (Boubtane et al., 2016; Bove \& Elia, 2017; Organisation for Economic Co-operation and Development, 2013).

Interaction effects greatly add to understanding of the relationships among remittances and foreign direct investment in the model. In the case of an interaction, it is expected that the variables are influencing each other but, depending on the expectations, the impact will be negative as that would mean that no variables substitute each other, regardless of whether the effect is negative, then it is understood that the influence of each is already stronger than in interaction (Bajra et al., 2021).

In addition to hypothesis (1), this study expands further by testing for the effects of international remittances on the reduction of inequality. The hypothesis is tested using the basic growth model introduced by Ravallion and Chen (1997). This model was used since it was suppose that economic growth, respectively an increase in mean per capita income, reduce inequality. Therefore, as presented above, the following model was used to measure the effect of remittances on lower inequality:

$$
\begin{gathered}
I_{i t}=\beta_{0}+\beta_{1} \text { inflowREM }_{i t}+\beta_{2} \text { inflowFDI }_{i t}+\beta_{3} \text { OpeEx }_{i t}+ \\
\beta_{4} \text { netMIG } \\
i t
\end{gathered}
$$

where $I n$ is the measure of inequality in country $i$ at time $t$ and stands as the second dependent variable in this study. This study uses the GINI coefficient to proxy for the inequality of income distribution among the population. In line with the explanation given above, all instrumental variables remain the same and represent the same input factors as shown in Eq. (3). Model in/of Eq. (4) also includes time-fixed effects $\left(e_{i t}\right)$, country effect $\left(u_{i t}\right)$, and error term $\left(\varepsilon_{i}\right)$. 
Eq. (4) shows the second basic model of the study used to measure the impact of emigrants' remittances on inequality reduction. Despite their large volume upon entrance to the economy, their effect on the economy cannot be bigger than on reducing inequality. A decrease in inequality also means an increase in the welfare in the population but, in contrast, the impact of inflowFDI is multidimensional and as well as showing the transfer of capital it is appropriate since as an endogenous factor it affects all economic activity, whether it be infrastructure, agriculture, trade, etc.

The free movement of goods and services is closely linked to the degree of openness of the economy (via Export). International trade represents the volume of exports in the economy, and the openness of the market is affected by the policies pursued by the state. It is assumed that a high level of exports means an economy is open and is accumulating capital, thereby leading to GDP growth, and so a positive relationship between OpeEx and inequality is expected.

Regarding net migration (the difference between immigration and emigration) and population growth, explained above that they exert a significant impact on reducing/increasing inequality in the region. Yet whether the effect is negative or vice-versa depends entirely on the level of development of a country.

\section{Empirical results}

\subsection{Descriptive statistics}

Table 1 presents the descriptive statistics for the variables examined in the study. As shown in Table 1, the GDP growth variable has a mean value of 3.7 percent while, as an absolute value, it ranges from USD 9.8 to USD 5,226 billion. Next, the average GINI index is 33.43, with a minimum of 26.30 (income distribution equality) and maximum of 41 (income distribution inequality). On average, remittance inflows for the whole period amount to USD 1,256 billion, with a maximum value of USD 4,650 billion. With respect to net migration, the mean sampled countries over the 19 -year period have -0.87 , with a maximum of -14.4 to 16.24 percent per thousand inhabitants. This finding may be interpreted as meaning the rate of emigration is higher than the immigration of the country-year observations. On the average for the countries, inflowFDI is 6.20 percent of GDP, with a minimum value of 0.54 to 37.27 percent over the 19-year period. Next, Table 1 reports that the countries' openness over the 19 -year period is 31.78 percent with a minimum value of 4.9 up to 61 percent of GDP.

Table 1. Descriptive statistics

\begin{tabular}{|l|c|c|c|c|c|}
\hline \multicolumn{1}{|c|}{ Variable } & Obs & Mean & Std. Dev. & Min & Max \\
\hline GDPMili & 120 & 13261 & 12889 & 984 & 52267 \\
\hline GDPgrowth (as \%) & 119 & 3.70 & 3.39 & -5.79 & 26.97 \\
\hline inflowREM (million) & 114 & 1256 & 1157 & 0.12 & 4650 \\
\hline inflowREM (as \% of GDP) & 120 & 9.50 & 7.01 & 0.00 & 29.00 \\
\hline GINIindex & 67 & 33.43 & 4.23 & 26.30 & 41.00 \\
\hline
\end{tabular}


End of Table 1

\begin{tabular}{|l|c|c|c|c|c|}
\hline \multicolumn{1}{|c|}{ Variable } & Obs & Mean & Std. Dev. & Min & Max \\
\hline NetMIG (per 1000 people) & 120 & -0.87 & 8.00 & -14.49 & 16.24 \\
\hline NetMIG (million) & 120 & -0.334 & 0.289 & -0.807 & 0.560 \\
\hline inflowFDI (million) & 120 & 835 & 1045 & 0 & 5749.37 \\
\hline inflowFDI (as \% of GDP) & 119 & 6.20 & 5.49 & 0.54 & 37.27 \\
\hline OpeEx (million) & 120 & 4595 & 5377.53 & 92.46 & 26656.17 \\
\hline OpeEx (as \% of GDP) & 120 & 31.78 & 11.24 & 4.90 & 61.00 \\
\hline Population (million) & 120 & 3358.6 & 2730.45 & 613 & 9488 \\
\hline infREM*infFDI & 113 & 8571 & 11478.81 & 0 & 83250.21 \\
\hline Age Dependency & 120 & 47.81 & 3.74 & 41.19 & 59.72 \\
\hline
\end{tabular}

Figure 1 also shows the trend of Diaspora remittances in relation to the GDP of each WB6 country. As may be seen, it was calculated the average remittances, namely the share of remittances in GDP over the 19-year period, which accounts for 10\% of GDP for the WB6 sample. In a time-trend analysis, the biggest share of remittances to GDP is received by Kosovo, then Bosnia, Albania, etc. It is interesting that remittances are falling every year, a clear indication that the connection of citizens with their countries of origin has already weakened. Northern Macedonia is associated with a smaller share in GDP at 3\%, indicating that its Diaspora is "aging" and ties with the country of origin have started to shrink extensively.

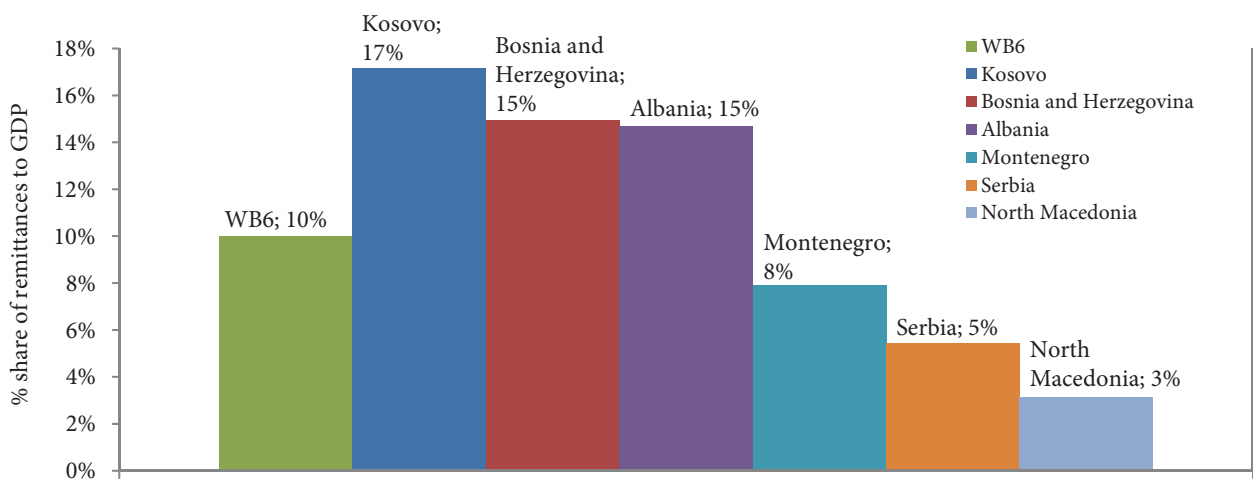

Remittance inflows to GDP 2000-2019 (on average)

Figure 1. Share of the participation of remittances in the GDP of the WB6 Countries

\subsection{Model testing and findings}

This section shows the test results of the model. Yet, before moving on to interpreting the results, some diagnostic tests related to model testing, namely the instrumental variables (IV) application, are presented.

First, since the unsystematic shocks that affect GDP growth in WB6 probably also affect remittances and inequality, by treating them both as endogenous. It is believe that the 
correlation between remittances and/or inequality and $u$ (error term) is not equal to zero. On the other hand, there is no reason to have confidence in the notion that the correlation between other instrumental variables and $u$ is nonzero, assuming that inflowFDI, OpeEx, and netMIG are exogenous. Running a test of endogeneity suggests that the inflowREM variable is exogenous (null hypothesis); therefore, it is fail to reject the null hypothesis that the variable is not exogenous at a significant level $(\mathrm{p}=0.000)$. Further, the problem with heteroskedasticity was analyzed to test if the standard error is not constant when a predictor variable rises. Basically, the spread of the errors is large for small values of independents variables and then becomes smaller as independent variables $\left(x_{i}\right)$ rise. It was noticed that the spread of the errors is constant across the $x_{i}$ values and thus it is ignore heteroskedasticity as a problem in further treatment. In this case, it use a weighting matrix that is optimal when the error term is heteroskedastic, thus, this matrix accounts for the error in period $t$ is probably correlated with the errors in periods $t-1, t-2$, etc., and also for serial correlation. Issues related to an overidentifying restriction or underidentifying restriction are also within the accepted parameters, suggesting the model is well balanced. In summary, using the Sargan and/or Hansen's J test, seems that it fail to reject the null hypothesis that the model is overpopulated or under-populated with variables. Although not so useful, for the same purpose it also ran Shea's test which summarizes the strength of the instruments as a single number. Additionally, it also checked whether panels contained unit roots, but it is failed to reject the hypothesis that the panels are unit roots at the significance level of p-value 0.011 , otherwise accepted the alternative hypothesis that panels are stationary.

This section continues to present the results of the test hypotheses, namely, models (1) and (2). The coefficients in this study are non-standardized and represent the original units of the variables.

As a start, this paper used OLS as the first method to proceed further with 2 SLS. The results of OLS are presented in Table 2 and 3, however they are not interpreted as the model is built on the IV estimator.

Table 2 shows the results of the first hypothesis on the relationship between remittances and growth. Consequently, it is find that remittances have a positive effect on economic growth and each 1-unit increase (1\% share in GDP) affects economic growth (GDP growth) by 0.10 percent at a $99.9 \%$ level of significance. This gives a valuable sign that the direct inflows of external resources in the form of remittances significantly affect the growth of output, but the magnitude is not high and therefore the study suggests a reasonable effect on economic growth. In addition, the impact of foreign direct investment also has a positive correlation with growth. With the same settings, Table 2 shows that the effect of infFDI is slightly higher than that of remittances and each unit (USD 1 million) of FDI will lead to an economic growth increase of at least 0.13 percent at a $99.99 \%$ level of significance. Also interesting are the results for Openness (OpeEx), confirming that the more open an economy, the greater the impact on it. A very interesting finding is the effect of population, showing that net migration has a negative impact on growth. In particular, an increase of 1,000 (i.e. persons) in negative migration (i.e., when the number of immigrants is less than the number of emigrants, a negative net migration rate occurs) is associated with a decline in economic growth (up to 0.05 percent decline). The effect of net migration is likely to affect the labor 
market as well since it absorbs the workforces, to some extent the qualified one. Table 2 shows that the interaction between inflowFDI and inflowREM is negative, to some extent suggesting that they complement rather than substitute each other. Thus, it is find that the negative interaction coefficient indicates that the effect of the combined action of remittances and foreign direct investments is less than the sum of the individual effects.

Table 2. Regression estimates of the effect of remittances on economic growth

\begin{tabular}{|c|c|c|}
\hline VARIABLES & OLS & 2SLS \\
\hline \multirow{2}{*}{ inflowREM } & $3.498^{\star * *}$ & $2.689^{* * *}$ \\
\hline & $(0.441)$ & $(0.453)$ \\
\hline \multirow{2}{*}{ inflowFDI } & $3.506^{\star * \star}$ & $3.470^{\star * \star}$ \\
\hline & $(0.492)$ & $(0.512)$ \\
\hline \multirow{2}{*}{ OpeEx } & $1.223^{\star * *}$ & $1.419^{\star * *}$ \\
\hline & $(0.109)$ & $(0.119)$ \\
\hline \multirow{2}{*}{ netMIG } & $-0.005^{* * *}$ & $-0.004^{* * *}$ \\
\hline & $(0.001)$ & $(0.000)$ \\
\hline \multirow{2}{*}{ infREM * infFDI } & $-0.100^{* * *}$ & $-0.081^{\star}$ \\
\hline & $(0.034)$ & $(0.034)$ \\
\hline \multirow{2}{*}{ Constant } & $1221.13^{* * *}$ & $2072.08^{* * *}$ \\
\hline & $(428.91)$ & $(1332.16)$ \\
\hline Observations & 114 & 113 \\
\hline$R$-squared & 0.94 & 0.95 \\
\hline Year effects & Yes & Yes \\
\hline Country effects & Yes & Yes \\
\hline Test of endogeneity ( $p$ value) & & 0.000 \\
\hline Shea's partial R-squared & & 0.002 \\
\hline $\begin{array}{l}\text { Test of overidentifying restriction } \\
\text { (Sargan) }\end{array}$ & & 0.000 \\
\hline
\end{tabular}

Note: Robust standard errors in parentheses. ${ }^{* *} \mathrm{p}<0.01,{ }^{* *} \mathrm{p}<0.05,{ }^{\star} \mathrm{p}<0.1$.

In addition to Table 2, Model 2 of Table 3 show the effect remittances have on inequality reduction. Inequality is linked to income distribution and economies are faced with an unequal distribution. In this respect, the results show that remittances affect ( 1 unit $=1 \%$ share in GDP) the reduction of inequality and for each unit inequality decreases by 0.05 percent at the sample level (as the GINI coefficient reduced from 33.43 to 31.78). Thus, high emigration does not have enough of an effect and, despite the weaker ties of the diaspora with its country of origin, it will still reduce income inequality. As the results of the regression show, its effect is very symbolic, that is to say, there is no effect at all. In addition, remittances had a further effect on creating marginalized layers of the population, becoming passive consumers. This situation does not favor economic development and, while it is difficult to achieve supplementing with other sources of financial funding. Next, the study find that FDI has wider effects on fighting inequalities than remittances. While the impact of FDI is positively 
linked to lower inequalities in the country, Table 3 also reports significant results in terms of openness. In addition to $O p e E X$, net migration tends to be negatively related to inequality. While net migration is negatively related to economic growth (Table 2), Table 3 also shows that negative migration can reduce inequality, but not to the extent that is claimed. Theoretically, the higher the migration, the greater the possibility of sending remittances to the country of origin, but not enough to affect the welfare of the country beyond raising the inequality threshold (i.e. to influence the increase of the income level). Remittances are typically used by the population for household consumption, and this increases the risk of damaging the labor market due to the habit of laziness that is nourished, while increasing age dependency among the silent majority (the people). The amount that comes in the form of remittances is potentially too small to target capital investment so the final destination remains largely consumption.

Table 3. Regression estimates of the effect of remittances on inequality

\begin{tabular}{|l|c|c|}
\hline \multirow{2}{*}{ VARIABLES } & OLS & 2 SLS \\
\hline \multirow{2}{*}{ inflowREM } & $0.002^{*}$ & $0.002^{* * *}$ \\
\hline \multirow{2}{*}{ inflowFDI } & $(0.001)$ & $(0.000)$ \\
\hline \multirow{2}{*}{ OpeEx } & $0.011^{* * *}$ & $0.235^{*}$ \\
\cline { 2 - 3 } & $(0.002)$ & $(0.136)$ \\
\hline \multirow{2}{*}{ netMIG } & 0.000 & $0.267^{* * *}$ \\
\hline \multirow{2}{*}{ infREM ${ }^{*}$ infFDI } & $(0.000)$ & $(0.037)$ \\
\hline \multirow{2}{*}{ Constant } & $0.000^{* * *}$ & $0.000^{* * *}$ \\
\cline { 2 - 3 } & $(0.000)$ & $(0.000)$ \\
\hline Observations & -0.001 & -0.000 \\
\hline R-squared & $(0.000)$ & $(0.000)$ \\
\hline Year effects & 29.489 & $24.75^{* * *}$ \\
\hline Country effects & $(2.714)$ & $(2.00)$ \\
\hline Test of endogeneity $(p$ value) & 66 & 59 \\
\hline Shea's partial $R$-squared & 0.71 & 0.65 \\
\hline $\begin{array}{l}\text { Test of overidentifying restriction } \\
\text { (Sargan) }\end{array}$ & Yes & Yes \\
\hline \multirow{2}{*}{ Note: Robust standard estors } & Yes & 0.000 \\
\cline { 2 - 3 } & & 0.574 \\
\hline
\end{tabular}

Note: Robust standard errors in parentheses. ${ }^{* * *} \mathrm{p}<0.01,{ }^{* *} \mathrm{p}<0.05,{ }^{\star} \mathrm{p}<0.1$.

\section{Conclusions}

This paper has examined the effect of remittances on economic growth and reducing income inequality by considering data from six Western Balkan countries. Although the impact of remittances is also been covered in previous literature, this paper generally complements 
the lack of literature on remittance-related issues in the WB6 region. Further, the paper is consistent with empirical evidence and the interpretation of the results was made according to the hypotheses being tested.

A significant link between remittances and economic growth should be expected, but their weights are not so distinguishable. In particular, the use of remittance targets for direct consumption makes it somewhat doubtful whether the multiplier effect of remittances can be considered in all economic segments. The kinds of remittances in WB6 mainly relate to personal remittances and the transfer of workers' salaries (i.e., employee compensation) to the country of origin, however, the share of remittances in the economy tends to decline as emigrants' ties to their countries of origin become weaker and, as a result, lower remittances to the WB6 have been observed in recent years. Another reason for this is the gradual loss of emigrant status and while transfers do not come in the form of remittances, they are offered through other channels such as foreign direct investment. Unlike remittances, foreign direct investment has a profound effect on economic growth. Although smaller in quantity, they have a monotonic linear effect on economic growth that is almost three times greater than that of remittances. The situation is the same in terms of exports where the links with economic growth are positive and significant. In terms of the ratio of individuals entering and leaving a country (net migration), the trend is negative and the effect on economic growth is also negative. This relates to the export of the workforce en route to developed countries that thereby weakens the labor market of the emigrant's country. This occurrence is worrying for the WB6 given that the influx of migrants is quite high, making the lack of workforce and increase in the age dependence of the population already noticeable. To this end, the effect is threefold as it relates to economic growth, the weakening of the labor market, and the creation of the population's dependency on remittances. On the other side, the effect of remittances remains irreplaceable by other external sources and therefore find that the individual effect of inflowFDI and inflowREM is greater than the interaction effect and that they do not substitute each other as long as complementarity is possible and proven. To conclude with regard to the first hypothesis, remittances are influential factor for accelerating economic growth but do not substitute other funding sources (i.e., inflowFDI); however, their impact extends to increasing the welfare of the people in several ways. From this perspective, the small share of remittances in GDP can be understood as blurring the link between migrants and their countries of origin, and vice versa. Certainly, the descendants in the second and third generations of migrant families do not fill the gap of remittances from abroad, and their spiritual connection with the country of origin of the descendants fades over time. But this phenomenon is also associated with the declining population growth in the WB6 countries.

With respect to the second hypothesis, the paper also show that remittances have a significant positive effect on reducing inequality in a country, albeit not to a large extent. This study does not support the claim that remittances have developmental effects, although they affect the reduction of inequalities in the country, do not affect the production capacity much or increase added value, with the exception that remittances are mainly used for consumption and thus increase purchasing power for basic things since the targets are passive layers of society.

Unlike measuring inflowFDI, OpeEx, netMIG, and the interaction of infREM ${ }^{*}$ infFDI on economic growth, the effect of these variables on reducing inequality is quite interesting. Of 
course, inequality reduction does not mean economic growth, but the effect of migration alleviates poverty and indirectly means less state funding for the marginalized stratum of society. So, negative migration is negatively related to economic growth, but on the other hand, although not strong, they have a positive effect on reducing inequality in the country. Therefore, a higher rate of people leaving the country than those entering and well-maintained connections (i.e., the young age of the diaspora) with family members, friends, or society influences migrant workers by way of sending some of the money they make back home, thereby alleviating the poverty that prevails in the country. Yet, as pointed out, ties fade as "the diaspora ages", and the burden of remittances continues to be borne by "new migrants", and thus we return to the claim that international migration is an ongoing process. In search of a better life, finding a job, and increasing well-being in generally, WB6 citizens will continue to migrate, and, despite the short-term effects, this will negatively affect economic growth, where individual migration is with an uncontrolled individual migration.

There is a growing view that remittances are important factors towards successful development efforts and reducing inequality. If so, then there may be significant policy implications from a development perspective because factors that upsurge economic cycle (i.e., inflowFDI, OpeEx, New Technology, regulatory policy, etc.) (Bajra \& Čadež, 2020), are likely to have economic returns beyond remittance returns and thus incline their impact on economic growth and reducing inequality. In addition to the impact on the economy and inequality, it also has long-term consequences that mainly affect the export of labor without distinction, then emptying the country of young people in search of a better perspective and possibly increases the possibility of age dependence. Furthermore, it is suggested that in addition to keeping ties with the diaspora, remittances be development-oriented, especially to encourage migrants through state policies that remittances be invested more in capital projects beyond household consumption. These issues should get the attention of policymakers, and the migration trend to take place in a controlled manner.

As with any study, this research has several limitations. In addition to the general limitations of archive-based research, a particular limitation of this study relates to the measurement of variables and aggregate data on which the paper is based. As noted in the study, remittances are not sufficiently addressed in WB6 and there is practically no perfect measurement of the remittances inflows. A similar limitation applies to the measurement of inequality. While this increases the potential to capture the inequality more inclusively, it also increases the likelihood of measurement error. These limitations, also pertinent to other studies, should however not preclude further research concerning remittances and inequalities. In particular, this study suggests it is worthwhile to investigate the effects of several social-economic factors simultaneously due to their potential interactive effects. In addition, the paper presents a series of limits generated in the first by the small number of developing countries included in the researched sample, which reduces the number of observations and the catching effect of remittances to be more comprehensive.

\section{Conflict of interest}

There is no conflict of interest associated with this research. 


\section{References}

Acosta, P., Calderón, C., Fajnzylber, P., \& Lopez, H. (2008). What is the impact of international remittances on poverty and inequality in Latin America? World Development, 36(1), 89-114. https://doi.org/10.1016/j.worlddev.2007.02.016

Adams, R. H., \& Cuecuecha, A. (2013). The impact of remittances on investment and poverty in Ghana. World Development, 50, 24-40. https://doi.org/10.1016/j.worlddev.2013.04.009

Alcaraz, C., Chiquiar, D., \& Salcedo, A. (2012). Remittances, schooling, and child labor in Mexico. Journal of Development Economics, 97(1), 156-165. https://doi.org/10.1016/j.jdeveco.2010.11.004

Alesina, A., \& Giuliano, P. (2010). The power of the family. Journal of Economic Growth, 15(2), 93-125. https://doi.org/10.1007/s10887-010-9052-Z

Amuedo-Dorantes, C., Georges, A., \& Pozo, S. (2010). Migration, remittances, and children's schooling in Haiti. The ANNALS of the American Academy of Political and Social Science, 630(1), 224-244. https://doi.org/10.1177/0002716210368112

Bajra, U. Q., Halili, Z., \& Berisha, N. (2020). Frontier economies and economic growth: Evidence from European and Central Asian Countries. Borsa Istanbul Review, 20(3), 279-291. https://doi.org/10.1016/j.bir.2020.04.002

Bajra, U. Q., Krasniqi, A., \& Podvorica, A. (2021). Privatisation of socially owned enterprises, the methods used and the impact on economic growth empirical evidence from Kosovo. Economic Research-Ekonomska Istraživanja, (forthcoming). https://doi.org/10.1080/1331677X.2021.1893201

Bajra, U. \& Čadež, S. (2020). Alternative regulatory policies, compliance and corporate governance quality. Baltic Journal of Management, 15(1), 42-60. https://doi.org/10.1108/BJM-11-2018-0373

Baškot, B. (2020). Capital flows impact on labor market: how do FDIs and remittances effect youth employment in Bosnia and Herzegovina? Economic Research-Ekonomska Istraživanja, 33(1), 26332647. https://doi.org/10.1080/1331677X.2020.1761418

Baum, C. F., Schaffer, M. E., \& Stillman, S. (2003). Instrumental variables and GMM: Estimation and testing. The Stata Journal: Promoting Communications on Statistics and Stata, 3(1), 1-31. https://doi.org/10.1177/1536867X0300300101

Bermejo Carbonell, J., \& Werner, R. A. (2018). Does foreign direct investment generate economic growth? A new empirical approach applied to Spain. Economic Geography, 94(4), 425-456. https://doi.org/10.1080/00130095.2017.1393312

Bertoli, S., \& Marchetta, F. (2014). Migration, remittances and poverty in ecuador. The Journal of Development Studies, 50(8), 1067-1089. https://doi.org/10.1080/00220388.2014.919382

Borensztein, E., De Gregorio, J., \& Lee, J.-W. (1998). How does foreign direct investment affect economic growth? Journal of International Economics, 45(1), 115-135. https://doi.org/10.1016/S0022-1996(97)00033-0

Boubtane, E., Dumont, J.-C., \& Rault, C. (2016). Immigration and economic growth in the OECD countries 1986-2006. Oxford Economic Papers, 68(2), 340-360. https://doi.org/10.1093/oep/gpw001

Bove, V., \& Elia, L. (2017). Migration, diversity, and economic growth. World Development, 89, 227-239. https://doi.org/10.1016/j.worlddev.2016.08.012

Brueckner, M., \& Lederman, D. (2018). Inequality and economic growth: the role of initial income. Journal of Economic Growth, 23(3), 341-366. https://doi.org/10.1007/s10887-018-9156-4

Bugamelli, M., \& Paternò, F. (2011). Output growth volatility and remittances. Economica, 78(311), 480-500. https://doi.org/10.1111/j.1468-0335.2009.00838.x

Carletto, C., Davis, B., Stampini, M., \& Zezza, A. (2006). A country on the move: International migration in post-communist Albania. International Migration Review, 40(4), 767-785.

https://doi.org/10.1111/j.1747-7379.2006.00043.x 
Chami, R., Ernst, E., Fullenkamp, C., \& Oeking, A. (2018). Are remittances good for labor markets in LICs, MICs and fragile states? (IMF Working Papers2018/102). https://doi.org/10.5089/9781484353615.001

Chowdhury, M. (2016). Financial development, remittances and economic growth: Evidence Using a dynamic panel estimation. Margin: The Journal of Applied Economic Research, 10(1), 35-54. https://doi.org/10.1177/0973801015612666

Cismaș, L. M., Curea-Pitorac, R. I., \& Vădăsan, I. (2019). The impact of remittances on the receiving country: Some evidence from Romania in European context. Economic Research-Ekonomska Istraživanja, 33(1), 1073-1094. https://doi.org/10.1080/1331677X.2019.1629328

Clemens, M. A., \& McKenzie, D. (2018). Why don't remittances appear to affect growth? The Economic Journal, 128(612), 179-209. https://doi.org/10.1111/ecoj.12463

Combes, J. L., Ebeke, C. H., Etoundi, S. M. N., \& Yogo, T. U. (2014). Are remittances and foreign aid a hedge against food price shocks in developing countries? World Development, 54, 81-98.

https://doi.org/10.1016/j.worlddev.2013.07.011

Dobson, J. R., \& Sennikova, I. (2007). From Fundamental freedom to Political and Economic 'hot potato' in 50 years: Labour mobility and migration within the EU. Journal of Business Economics and Management, 8(2), 123-136. https://doi.org/10.3846/16111699.2007.9636160

Dominese, G., Yakubovskiy, S., Tsevukh, J., \& Rodionova, T. (2020). Impact of international migration flows on the European union and Ukraine. Transition Studies Review, 27(2), 83-98. https://doi.org/10.14665/1614-4007-27-2-007

Duval, L., \& Wolff, F.-C. (2016). Do remittances support consumption during crisis? Evidence from Kosovo. Oxford Development Studies, 44(4), 479-492. https://doi.org/10.1080/13600818.2016.1156080

Erman, L., \& te Kaat, D. M. (2019). Inequality and growth: industry-level evidence. Journal of Economic Growth, 24(3), 283-308. https://doi.org/10.1007/s10887-019-09169-z

Etonam Adetou, A., \& Fiodendji, K. (2019). Finance, institutions, remittances and economic growth: New evidence from a dynamic panel threshold analysis. Journal of Applied Finance \& Banking, 9(2), 1792-6599.

Gapen, M. T., Chami, R., Montiel, P., Barajas, A., \& Fullenkamp, C. (2009). Do workers' remittances promote economic growth? IMF Working Papers, 2009/153. https://doi.org/10.5089/9781451873009.001

Grossman, G. M., \& Helpman, E. (1994). Endogenous innovation in the theory of growth. Journal of Economic Perspectives, 8(1), 23-44. https://doi.org/10.1257/jep.8.1.23

Guha, P. (2013). Macroeconomic effects of international remittances: The case of developing economies. Economic Modelling, 33, 292-305. https://doi.org/10.1016/j.econmod.2013.04.016

Haas, H. De. (2007). Remittances, migration and social development a conceptual review of the literature. social policy. https://www.unrisd.org/80256B3C005BCCF9/search/8B7D005E37FFC77EC125 $73 \mathrm{~A} 600439846$

Haas, H., Czaika, M., Flahaux, M., Mahendra, E., Natter, K., Vezzoli, S., \& Villares-Varela, M. (2019). International migration: Trends, determinants, and policy effects. Population and Development Review, 45(4), 885-922. https://doi.org/10.1111/padr.12291

Haller, A., Butnaru, R., \& Butnaru, G. (2018). International migrant remittances in the context of economic and social sustainable development. a comparative study of Romania-Bulgaria. Sustainability, 10(4), 1156. https://doi.org/10.3390/su10041156

Hanushek, E. A. (2013). Economic growth in developing countries: The role of human capital. Economics of Education Review, 37, 204-212. https://doi.org/10.1016/j.econedurev.2013.04.005

Hye, Q. M. A., \& Lau, W.-Y. (2014). Trade openness and economic growth: Empirical evidence from India. Journal of Business Economics and Management, 16(1), 188-205.

https://doi.org/10.3846/16111699.2012.720587 
Imai, K. S., Gaiha, R., Ali, A., \& Kaicker, N. (2014). Remittances, growth and poverty: New evidence from Asian countries. Journal of Policy Modeling, 36(3), 524-538. https://doi.org/10.1016/j.jpolmod.2014.01.009

International Monetory Fund. (2009). International transactions in remittances guide for compilers and users. International Monetory Fund. www.imfbookstore.org

Karpestam, R. P. D. (2012). Dynamic multiplier effects of remittances in developing countries. Journal of Economic Studies, 39(5), 512-536. https://doi.org/10.1108/01443581211259455

Keho, Y. (2017). The impact of trade openness on economic growth: The case of Cote d'Ivoire. Cogent Economics \& Finance, 5(1). https://doi.org/10.1080/23322039.2017.1332820

King, R., \& Vullnetari, J. (2009). Remittances, return, diaspora: Framing the debate in the context of Albania and Kosova. Journal of Southeast European and Black Sea, 9(4), 385-406. https://doi.org/10.1080/14683850903314907

KNOMAD. (2020). Global Knowledge Partnership on Migration and Development. https://www.knomad.org/data/remittances

Kubis, A., \& Schneider, L. (2016). Regional migration, growth and convergence - a spatial dynamic panel model of Germany. Regional Studies, 50(11), 1789-1803. https://doi.org/10.1080/00343404.2015.1059932

Kuznets, S. (2019). Economic growth and income inequality. In The gap between rich and poor (pp. 25-37). Routledge. https://doi.org/10.4324/9780429311208-4

Lartey, E. K. K. (2013). Remittances, investment and growth in sub-Saharan Africa. The Journal of International Trade \& Economic Development, 22(7), 1038-1058. https://doi.org/10.1080/09638199.2011.632692

Mccallum, B. T. (1996). Neoclassical vs. endogenous growth analysis: An overview. FRB Richmond Economic Quarterly, 82(4), 41-71. https://doi.org/10.3386/w5844

Mehedintu, A., Soava, G., \& Sterpu, M. (2019). Remittances, migration and gross domestic product from Romania's perspective. Sustainability, 12(1), 212. https://doi.org/10.3390/su12010212

Mendoza, C. (2020). Southern Europe skilled migration into Mexico: the impact of the economic crisis. Regional Studies, 54(4), 495-504. https://doi.org/10.1080/00343404.2018.1447101

Organisation for Economic Co-operation and Development. (2013). International migration outlook 2013. OECD. https://doi.org/10.1787/migr_outlook-2013-en

Peterson, E. W. F. (2017). The role of population in economic growth. SAGE Open, 7(4), 1-15. https://doi.org/10.1177/2158244017736094

Polat, B., \& Rodríguez Andrés, A. (2019). Do emigrants' remittances cause Dutch disease? A developing countries case study. The Economic and Labour Relations Review, 30(1), 59-76. https://doi.org/10.1177/1035304619828560

Pradhan, G., Upadhyay, M., \& Upadhyaya, K. (2008). Remittances and economic growth in developing countries. The European Journal of Development Research, 20(3), 497-506. https://doi.org/10.1080/09578810802246285

Rausser, G., Strielkowski, W., Bilan, Y., \& Tsevukh, Y. (2018). Migrant remittances and their impact on the economic development of the Baltic states. Geographica Pannonica, 22(3), 165-175. https://doi.org/10.5937/gp22-16988

Ravallion, M., \& Chen, S. (1997). What can new survey data tell us about recent changes in distribution and poverty? The World Bank Economic Review, 11(2), 357-382. https://doi.org/10.1093/wber/11.2.357

Rodriguez, E. R., \& Tiongson, E. R. (2001). Temporary migration overseas and household labor supply: Evidence from urban Philippines. International Migration Review, 35(3), 709-725. https://doi.org/10.1111/j.1747-7379.2001.tb00037.x 
Romer, C. D., \& Romer, D. H. (2010). The macroeconomic effects of tax changes: Estimates based on a new measure of fiscal shocks. American Economic Review, 100(3), 763-801. https://doi.org/10.1257/aer.100.3.763

Saadi, M. (2020). Remittance inflows and export complexity: New evidence from developing and emerging countries. The Journal of Development Studies, 56(12), 2266-2292. https://doi.org/10.1080/00220388.2020.1755653

Sebastian, A., la O Campos, A. P., Daidone, S., Pace, N., Davis, B., Niang, O., \& Pellerano, L. (2019). Cash transfers and gender differentials in child schooling and labor: Evidence from the Lesotho child grants programme. Population and Development Review, 45(S1), 181-208. https://doi.org/10.1111/padr.12269

Sobiech, I. (2019). Remittances, finance and growth: Does financial development foster the impact of remittances on economic growth? World Development, 113, 44-59. https://doi.org/10.1016/j.worlddev.2018.08.016

Wietzke, F. B. (2020). Poverty, inequality, and fertility: The contribution of demographic change to global poverty reduction. Population and Development Review, 46(1), 65-99. https://doi.org/10.1111/padr.12317

Wooldridge, J. M. (2013). Introductory econometrics: A modern approach (5th ed.). South-Western Cengage Learning.

World Bank. (2019). Leveraging economic migration for development. https://www.knomad.org/sites/default/files/2019-08/World Bank Board Briefing Paper-LEVERAGING ECONOMIC MIGRATION FOR DEVELOPMENT_0.pdf 